\title{
Evaluating Efficacy of High Density Planting in Banana under Coastal Plain Zone of Odisha
}

\author{
Saudamini Swain ${ }^{1 *}$, Bipin Pradhan ${ }^{1}$ and Prakash Patil ${ }^{2}$ \\ ${ }^{1}$ All India Coordinated Research Project on fruits (ICAR), Odisha University of Agriculture \\ and Technology, Bhubaneswar-751003, India \\ ${ }^{2}$ IIHR, Hessarghat, Bengaluru, India \\ *Corresponding author
}

\section{A B S T R A C T}

\begin{tabular}{|l|}
\hline Ke y w or d s \\
$\begin{array}{l}\text { High density } \\
\text { planting, Banana, } \\
\text { Growth and Bunch } \\
\text { yield }\end{array}$ \\
\hline Article Info \\
$\begin{array}{l}\text { Accepted: } \\
\text { 04 October } 2020 \\
\text { Available Online: } \\
\text { 10 November } 2020\end{array}$ \\
\hline
\end{tabular}

Keywords

High density planting, Banana, Growth and Bunch mber 2020

\section{Introduction}

Banana (Musa spp.) is the $2^{\text {nd }}$ most important fruit crop in India next to mango. Bananas are important components of food security in the tropical world and provide income to the farming community through local and international trade. Banana is a very popular fruit due to its low price and high nutritive value. It is a rich source of carbohydrate and vitamins particularly vitamin B. It is also a good source of potassium, phosphorus, calcium and magnesium. The fruit is easy to digest, free from fat and cholesterol. Banana plants also provide useful by-products, such as fiber, vegetables, beer, wine and vinegar (Aurore et al., 2009). In India, bananas are commercially grown in the states of Tamil Nadu, Maharashtra, Gujarat, Karnataka, Andhra Pradesh, Telangana, Madhya Pradesh, Kerala, Odisha, Bihar, eastern U.P., West Bengal and Assam.

Banana yield more particularly its productivity could be enhanced profitably by adopting different approaches like use of high 
yielding varieties, adoption of high density planting techniques, drip and fertigation technologies and integrated nutrient management as well as plant protection measures. Among these approaches, high density planting (HDP) is one of the recent and novel approaches in enhancing the productivity. High density planting (HDP) in banana is an intensive system of cultivation and it enhances bunch yield giving more profit to the farmers. This system of cultivation facilitates efficient utilization of solar energy, nutrients and water (Apshara and Sathiamoorthy, 2003) and was proven successful in increasing productivity. Besides higher yield, HDP also helps to reduce labour cost and increase the efficiency of input utilization. Planting of three suckers per pit under high density planting consumed less water than normal planting of one sucker per pit, thus enhanced the water productivity in banana cultivation. Besides, closer spacing prevent natural hazards especially wind speed during storm. In the present investigation we studied the effect of high density planting on two varieties of banana in closer and wider spacing under coastal plain zone of Odisha.

\section{Materials and Methods}

The investigation was undertaken in the experimental plot of AICRP on Fruits, Odisha University of Agriculture and Technology (O.U.A.T.), Bhubaneswar, Odisha during the year 2014-15. The Horticulture research Station (HRS) is located at the latitude of $20^{\circ} 15^{\prime} \mathrm{N}$ and longitude of $85^{\circ} 52^{\prime} \mathrm{E}$. The experiment was conducted on sandy clay loam soil with $\mathrm{PH}$ 4.57. This experiment comprised of six treatments and was laid in randomized block design with four replications. The treatments included T1variety Bantala (V1) with spacing $2 \mathrm{~m} \times 3 \mathrm{~m}$ (S1; 3 suckers/pit \& 5001 plants/ha), T2variety Bantala (V1) with spacing $1.8 \mathrm{~m} \times 3.6$ m (S2; 3 suckers/pit \& 4629 plants/ha), T3- variety Bantala (V1) with spacing $1.8 \mathrm{~m} \times 1.8$ $\mathrm{m}$ (S3; 1 sucker /pit \& 3086 plants/ha) (Normal spacing), T4- variety Grand Naine (V2) with spacing $2 \mathrm{~m} \times 3 \mathrm{~m}$ (S1), T5- variety Grand Naine (V2) with spacing $1.8 \mathrm{~m} \times 3.6 \mathrm{~m}$ (S2), T6- variety Grand Naine (V2) with spacing $1.8 \mathrm{~m} \times 1.8 \mathrm{~m}$ (S3; Normal spacing). All cultural practices were followed to raise a good crop. Half of recommended dose of $\mathrm{N}$, $\mathrm{P}_{2} \mathrm{O}_{5}, \mathrm{~K}_{2} \mathrm{O}$ was applied per plant in $\mathrm{S} 1 \& \mathrm{~S} 2$ while $100 \%$ in the case of S3. For treatments S1 \& S2, foliar spray of urea $(0.5 \%)+$ sulphate of potash $(0.5 \%)+\mathrm{ZnSO}_{4}(0.2 \%)+$ $\mathrm{H}_{3} \mathrm{BO}_{3}(0.1 \%)$ was too given at 4,6 and 8 months after planting. One sucker as "follower" was allowed per plant in a pit at the time of shooting. Other suckers were periodically removed. Observations on plant height, pseudo-stem girth, number of leaves/plant, days taken for shooting, days taken for harvesting, number of hands/bunch and bunch weight were recorded in each replication of all the treatments. Economics of the treatments were calculated as per prevailing market price.

\section{Results and Discussion}

\section{Growth parameters}

Analysis of variance indicated significant differences among the treatments for different growth parameters recorded during the years 2014-15, 2015-16 and 2016-17. From the data (Table 1), it was revealed that during the years 2014-15, 2015-16 and 2016-17 the variety Bantala (ABB) recorded the maximum pseudo-stem height (275.0, 278.40, 275.60 $\mathrm{cm})$ at a spacing of $2 \mathrm{~m} \times 3 \mathrm{~m}$ with 3 suckers (T1) followed by T2 (spacing $1.8 \mathrm{~m} \times 3.6 \mathrm{~m}$ with 3 suckers per pit) and T1(spacing $1.8 \mathrm{~m}$ $\times 1.8 \mathrm{~m}$ with 1 sucker per pit). The variety Bantala showed significantly higher plant height as compared to the variety Grand Naine (AAA) during these three years which may be due to difference in genotypic 
potential. The variety Grand Naine recorded the maximum pseudo-stem height of 185.00 $\mathrm{cm}, 188.60 \mathrm{~cm}$ and $189.70 \mathrm{~cm}$ at a spacing of $2 \mathrm{~m} \times 3 \mathrm{~m}$ with 3 suckers per pit (T1) during the years 2014-15, 2015-16 and 2016-17 followed by T2 (spacing $1.8 \mathrm{~m} \times 3.6 \mathrm{~m}$ with 3 suckers per pit) and T1 (spacing $1.8 \mathrm{~m} \times 1.8$ $\mathrm{m}$ with 1 sucker per pit). Mean data over three years indicated that spacing of $2 \mathrm{~m} \mathrm{x} 3 \mathrm{~m}$ with 3 suckers per pit recorded the highest height in both varieties i.e. Bantala $(276.33 \mathrm{~cm})$ and Grand Naine $(187.77 \mathrm{~cm})$ and the lowest height for the same varieties was recorded at the spacing of $1.8 \mathrm{~m} \times 1.8 \mathrm{~m}$ with 1 sucker per pit $(264.90$ and $178.20 \mathrm{~cm})$. However, there was no significant difference noticed under different spacings within the variety. Observations on pseudo-stem girth at harvesting time were presented in Table 1. From the Table 1, it was revealed that significant differences existed among the treatments. In the year 2014-15, Bantal attained maximum girth $(69.30 \mathrm{~cm})$ at a spacing of $1.8 \mathrm{~m} \times 1.8 \mathrm{~m}$ with 1 sucker per pit and minimum girth $(66.00 \mathrm{~cm})$ at a spacing of $2.0 \mathrm{~m} \times 3.0 \mathrm{~m}$ with 3 suckers per pit. The trend was same during the years 2014-15, 2015-16 \& 2016-17. In case of Grand Naine, pseudo stem girth as recorded during the years 2014-15, 2015-16 \& 2016-17 was found to be minimum at a spacing of $2.0 \mathrm{~m} \times 3.0 \mathrm{~m}$ with 3 suckers per pit $(56.40,57.20,57.70$ $\mathrm{cm})$ as compared to the spacing of $1.8 \mathrm{~m} \times 3.6$ $\mathrm{m}$ with 3 suckers per pit and $1.8 \mathrm{~m} \times 1.8 \mathrm{~m}$ with 1 sucker per pit. Mean data pooled over three years revealed that Bantal and Grand Naine attained maximum girth $(70.00 \mathrm{~cm}$ \& $64.33 \mathrm{~cm}$ ) at a spacing of $1.8 \mathrm{~m} \times 1.8 \mathrm{~m}$ with 1 sucker per pit. As far as the varieties were concerned, Bantala showed higher pseudostem girth compared to Grand Naine. In both the cases, due to placement of three plants per pit the competition for space and light might have made the plants taller and lanky as a result of which the plant height recorded was more and girth was the least under the spacing accommodating highest number of plants/ha Similar result were reported by Badgujar and Gawade (2007) and Kumar and Kumar (2011) whose findings are similar with the present work.

Effect of high density planting on number of leaves/plant of variety Bantal and Grand Naine was depicted in Fig. 1. In case of variety Bantal, number of leaves per plant during the years 2014-15 \& 2015-16 was found to be the highest in T1 $(13.00,12.41)$ as compared to $\mathrm{T} 2(12.33,12.24)$ but during the year 2016-17 more number of leaves were observed in T2 (12.11) than T1 (11.70). The lowest number of leaves/plant was observed in T3 $(11.33,11.24,11.56)$ in these three years. The trend observed in pooled data indicated that $\mathrm{T} 1$ was better than $\mathrm{T} 2$ and $\mathrm{T} 3$. Mean data pooled over three years indicated that the variety Grand Naine produced the highest number of leaves (13.42) at a spacing of $2.0 \mathrm{~m} \times 3.0 \mathrm{~m}$ with 3 suckers per pit (T4). In both the varieties, high density planting at a spacing of $2.0 \mathrm{~m} \times 3.0 \mathrm{~m}$ with three plants per pit gave the highest number of leaves where as under low density planting at a spacing of $1.8 \mathrm{~m} \times 1.8 \mathrm{~m}$ with one plant per pit, the number of leaves was less. This work is in confirmation with the works reported by Nalina et al., (2000).

\section{Days to shooting and harvesting}

Days to shooting and harvesting give information regarding earliness of the varieties. In the present investigation the treatments showed significant variation for shooting and harvesting time (Table 2). The variety Bantal took 259.33, 262.60 and 263.40 days for shooting during the year 2014-15, 2015-16 and 2016-17 at a spacing of $2 \mathrm{~m} \times 3 \mathrm{~m}$ with 3 suckers (T1). It took 259.67, 260.20 and 258.83 days for shooting when planted at a spacing of $1.8 \mathrm{~m} \times 3.6 \mathrm{~m}$ with 3 suckers (T2) in the year 2014-15, 2015-16 
and 2016-17 respectively. When planting was done at a spacing of $1.8 \mathrm{~m} \mathrm{x} 1.8 \mathrm{~m}$ with 1 sucker per pit (T3), it took 257.33, 259.40 and 258.50 days for shooting in the year 2014-15, 2015-16 and 2016-17 respectively. It was observed no significant differences between $\mathrm{T} 1, \mathrm{~T} 2$ and $\mathrm{T} 3$.

The variety Grand Naine took 243.00, 244.51 and 243.41 days for shooting during the years 2014-15, 2015-16 and 2016-17 at a spacing of $2 \mathrm{~m} \times 3 \mathrm{~m}$ with 3 suckers per pit (T4). It took 243.33, 241.40 and 242.30 days for shooting when planted at a spacing of $1.8 \mathrm{~m} \times 3.6 \mathrm{~m}$ with 3 suckers per pit (T5) in the years 201415, 2015-16 and 2016-17 respectively. When planting was done at a spacing of $1.8 \mathrm{~m} \mathrm{x} 1.8$ m with 1 sucker per pit (T6), it took 238.90, 238.62 and 239.20 days for shooting in the years 2014-15, 2015-16 and 2016-17 respectively. Planting of Grand Naine at a spacing of $2 \mathrm{~m} \mathrm{x} 3 \mathrm{~m}$ with 3 suckers per pit took significantly more time for shooting as compared to planting at a spacing of $1.8 \mathrm{~m} \mathrm{x}$ $1.8 \mathrm{~m}$ with 1 sucker per pit during these three years. Pooled analysis indicated that the plantain (cv. Bantal) had taken significantly more days for shooting as compared to dessert banana (cv. Grand Naine). In both the varieties early shooting appeared at a spacing of $1.8 \mathrm{~m} \mathrm{x} 1.8 \mathrm{~m}$ with 1 sucker per pit as compared to high density planting.

Table.1 Effect of high density planting on height and girth of pseudo stem

\begin{tabular}{|c|c|c|c|c|c|c|c|c|}
\hline Treatment & \multicolumn{4}{|c|}{ Pseudo stem height (cm) } & \multicolumn{4}{c|}{ Pseudo stem girth (cm) } \\
\cline { 2 - 12 } & $2014-15$ & $2015-16$ & $2016-17$ & Mean & $2014-15$ & $2015-16$ & $2016-17$ & Mean \\
\hline T1(V1S1) & 275.00 & 278.40 & 275.60 & 276.33 & 66.00 & 67.20 & 66.40 & 66.53 \\
\hline T2(V1S2) & 266.00 & 266.80 & 267.60 & 266.80 & 67.00 & 69.40 & 69.30 & 68.57 \\
\hline T3(V1S3) & 263.00 & 268.60 & 264.90 & 265.50 & 69.30 & 70.50 & 70.20 & 70.00 \\
\hline T4(V2S1) & 185.00 & 188.60 & 189.70 & 187.77 & 58.50 & 56.40 & 57.20 & 57.37 \\
\hline T5(V2S2) & 181.00 & 180.40 & 181.20 & 180.86 & 60.17 & 62.40 & 63.10 & 61.89 \\
\hline T6(V2S3) & 179.00 & 178.20 & 176.40 & 177.87 & 63.50 & 64.60 & 65.10 & 64.33 \\
\hline CD(0.05) & $\mathbf{1 . 6 3}$ & $\mathbf{9 . 2 3}$ & $\mathbf{1 9 . 4 3}$ & $\mathbf{1 6 . 4 2}$ & $\mathbf{1 . 4 7}$ & $\mathbf{4 . 4 0}$ & $\mathbf{4 . 1 4}$ & $\mathbf{4 . 2 1}$ \\
\hline CV & $\mathbf{1 0 . 4 5}$ & $\mathbf{1 0 . 2 3}$ & $\mathbf{5 . 9 1}$ & $\mathbf{6 . 2 4}$ & $\mathbf{1 . 2 7}$ & $\mathbf{1 1 . 5 3}$ & $\mathbf{4 . 3 6}$ & $\mathbf{5 . 2 1}$ \\
\hline
\end{tabular}

Table.2 Effect of high density planting on days taken for shooting and harvesting

\begin{tabular}{|c|c|c|c|c|c|c|c|c|}
\hline \multirow{2}{*}{ Treatment } & \multicolumn{4}{|c}{ Days taken for shooting } & \multicolumn{4}{c|}{ Days taken for harvesting } \\
\cline { 2 - 10 } & $2014-15$ & $2015-16$ & $2016-17$ & Mean & $2014-15$ & $2015-16$ & $2016-17$ & Mean \\
\hline T1 & 259.33 & 262.60 & 263.40 & 261.77 & 351.33 & 355.60 & 353.60 & 353.51 \\
\hline T2 & 259.67 & 260.20 & 258.83 & 259.57 & 349.00 & 354.20 & 348.50 & 350.57 \\
\hline T3 & 257.33 & 259.40 & 258.50 & 258.41 & 347.00 & 348.90 & 349.40 & 348.43 \\
\hline T4 & 243.00 & 244.51 & 243.41 & 243.64 & 336.33 & 332.40 & 331.40 & 333.38 \\
\hline T5 & 243.33 & 241.40 & 242.30 & 242.34 & 333.67 & 331.10 & 331.20 & 331.99 \\
\hline T6 & 238.90 & 238.62 & 239.20 & 238.91 & 329.00 & 332.20 & 331.10 & 330.77 \\
\hline CD(0.05) & $\mathbf{4 . 3 1}$ & $\mathbf{5 . 8 5}$ & $\mathbf{6 . 9 7}$ & $\mathbf{1 7 . 4 0}$ & $\mathbf{6 . 5 8}$ & $\mathbf{1 0 . 4 5}$ & $\mathbf{7 . 1 2}$ & $\mathbf{1 8 . 4 0}$ \\
\hline CV & $\mathbf{9 . 4 5}$ & $\mathbf{7 . 4 5}$ & $\mathbf{9 . 1 1}$ & $\mathbf{9 . 4 5}$ & $\mathbf{1 1 . 3 2}$ & $\mathbf{1 0 . 4 2}$ & $\mathbf{5 . 4 3}$ & $\mathbf{1 0 . 2 1}$ \\
\hline
\end{tabular}


Table.3 Effect of high density planting on number of hands/bunch and bunch weight

\begin{tabular}{|c|c|c|c|c|c|c|c|c|c|}
\hline \multirow{2}{*}{ Treatment } & \multicolumn{4}{|c|}{ No.of hands/bunch } & \multicolumn{4}{c|}{ Bunch weight (kg/plant) } \\
\cline { 2 - 11 } & $2014-15$ & $2015-16$ & $2016-17$ & Mean & $2014-15$ & $2015-16$ & $2016-17$ & Mean \\
\hline T1 & 7.60 & 7.16 & 7.14 & 7.30 & 13.07 & 13.40 & 12.57 & 13.00 \\
\hline T2 & 7.42 & 7.31 & 7.56 & 7.43 & 13.40 & 13.60 & 12.94 & 13.31 \\
\hline T3 & 7.95 & 8.09 & 8.13 & 8.06 & 13.87 & 14.20 & 14.23 & 14.10 \\
\hline T4 & 9.98 & 10.19 & 10.21 & 10.13 & 19.03 & 17.40 & 18.31 & 18.25 \\
\hline T5 & 10.29 & 10.41 & 10.35 & 10.35 & 18.00 & 18.20 & 18.35 & 18.33 \\
\hline T6 & 11.31 & 11.23 & 11.32 & 11.30 & 20.77 & 20.80 & 20.51 & 20.70 \\
\hline CD(0.05) & $\mathbf{0 . 1 9}$ & $\mathbf{0 . 8 9}$ & $\mathbf{1 . 5 1}$ & $\mathbf{0 . 9 8}$ & $\mathbf{0 . 8 4}$ & $\mathbf{0 . 4 1}$ & $\mathbf{1 . 1 5}$ & $\mathbf{1 . 1 4}$ \\
\hline CV & $\mathbf{1 . 5 5}$ & $\mathbf{8 . 6 2}$ & $\mathbf{1 1 . 3 6}$ & $\mathbf{5 . 2 4}$ & $\mathbf{2 . 9 2}$ & $\mathbf{6 . 8 4}$ & $\mathbf{9 . 4 0}$ & $\mathbf{9 . 3 8}$ \\
\hline
\end{tabular}

Table.4 Effect of high density planting on bunch yield and B:C ratio

\begin{tabular}{|c|c|c|c|c|}
\hline \multirow{2}{*}{ Treatment } & \multicolumn{4}{|c|}{ Bunch yield (ton/ha) } \\
\cline { 2 - 5 } & $2014-15$ & $2015-16$ & $2016-17$ & Mean \\
\hline T1 & 68.51 & 65.39 & 62.86 & 65.59 \\
\hline T2 & 62.03 & 62.95 & 59.90 & 61.63 \\
\hline T3 & 42.79 & 43.82 & 43.91 & 43.51 \\
\hline T4 & 96.52 & 87.02 & 91.57 & 91.70 \\
\hline T5 & 83.32 & 84.25 & 84.94 & 84.17 \\
\hline T6 & 64.09 & 64.19 & 63.29 & 63.86 \\
\hline CD(0.05) & $\mathbf{3 . 9 6}$ & $\mathbf{1 . 8 0}$ & $\mathbf{5 . 4 3}$ & $\mathbf{3 . 3 1}$ \\
\hline
\end{tabular}

Fig.1 Effect of high density planting on number of leaves/plant

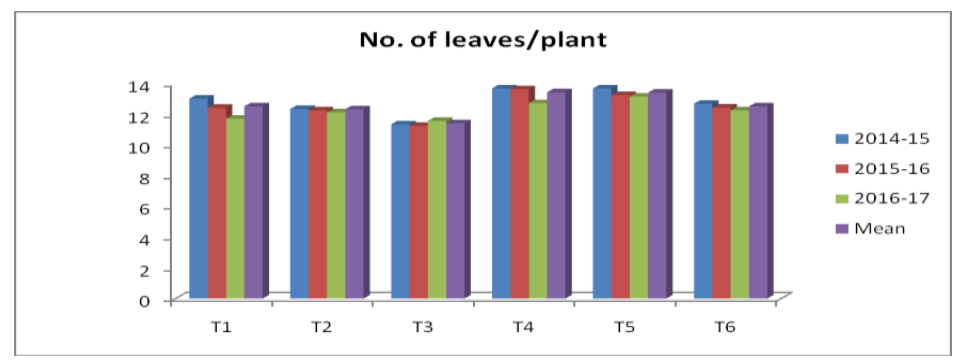

Fig.2 Bunch weight (average of 3 years) of Bantal and Grand Naine at different spacing

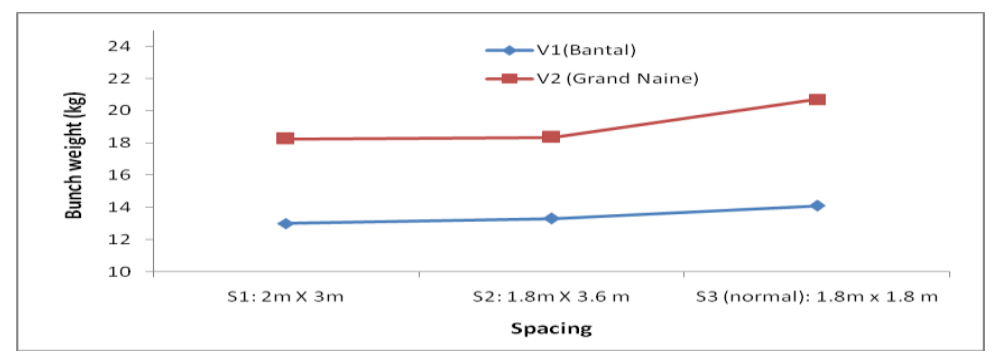


Fig.3 Bunch weight (av. of 3 years) of Bantal and Grand Naine at different spacing

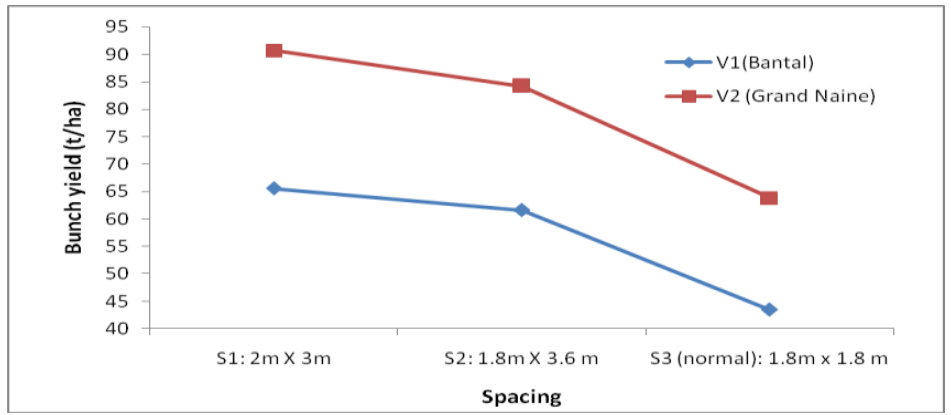

Fig.4 Scatter plot of bunch yield and B:C ratio of Bantal and Grand Naine

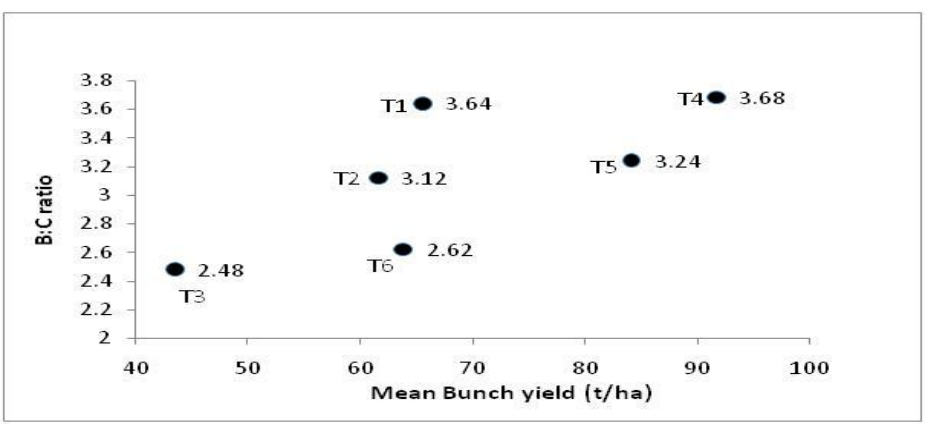

Plate.1 Field view of experimental plot

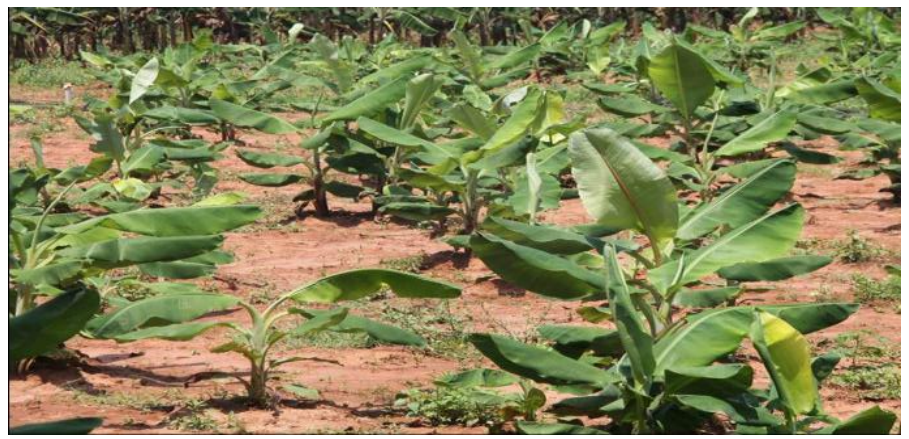

Plate.2 Planting banana at 3 suckers per pit (Grand Naine)

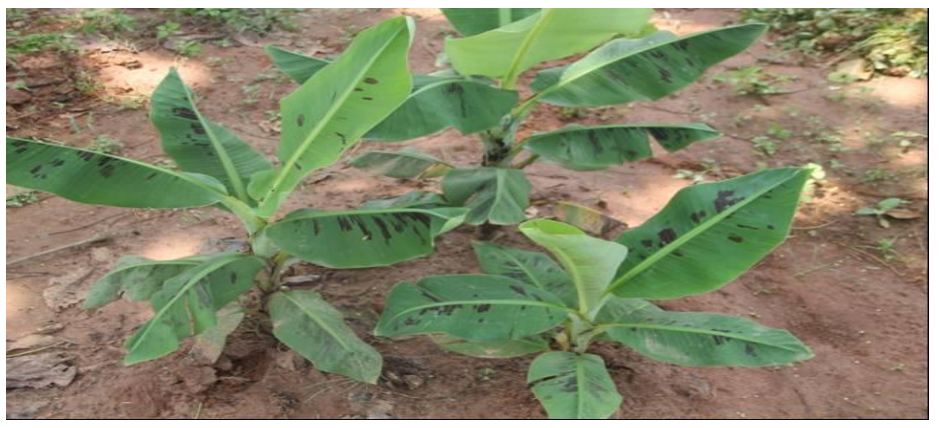




\section{Plate.3 Planting banana at 3 suckers per pit (Bantal)}

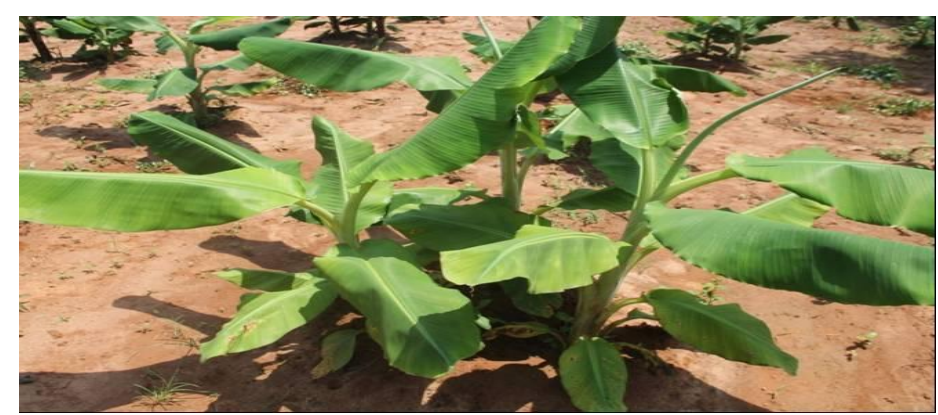

Similar trend was noticed for harvesting days in both the varieties during the years 2014-15, 2015-16 and 2016-17. Pooled analysis in respect of harvesting days indicated that in both the varieties early harvesting occurred at a spacing of $1.8 \mathrm{~m} \times 1.8 \mathrm{~m}$ with 1 sucker per pit (Bantal: 348.33 days; Grand Naine: 330.77 days). Comparatively short period of late shooting and harvesting in both the varieties under high density planting may be due to shading effect of leaves that might have caused reduced photosynthetic activity.

\section{Yield attributing characters}

\section{Number of hands per bunch}

The results on number of hands per bunch (Table 3) exhibited significant differences among the treatments. During the planting year 2014-15, it was observed that number of hands per bunch in variety Bantal was significantly lower in T1 (7.60) and T2 (7.42) as compared to T3 (7.95). In the year 201516, T1 (7.16) was significantly lower than T3 (8.09) and in the year 2016-17, T1(7.14) and T2 (7.56) were at par with T3 (8.13). In case of Grand Naine, T4 and T5 recorded significantly lower number of hands per bunch than T6 in the year 2014-15; T4 recorded significantly lower number of hands per bunch (10.19) than T6 (11.23) in the year 2015-16 and T4 (10.21) and T5 (10.35) were at par with T6 (11.32) in regards to number of hands per bunch during the year 2016-17.
Pooled analysis revealed that both the varieties Bantal and Grand Naine at normal spacing $(1.8 \mathrm{~m} \times 1.8 \mathrm{~m})$ with one plant per pit showed more number of hands per bunch as compared to high density planting i.e. in spacing $2 \mathrm{~m} \times 3 \mathrm{~m}$ (5001plants/ha) and 1.8 $\mathrm{m} \times 3.6 \mathrm{~m}$ (4629 plants/ha).

\section{Bunch weight}

During the planting year 2014-15, it was observed that bunch weight of the variety Bantal in T1 (13.07 kg/plant) and T2 (13.40 $\mathrm{kg} /$ plant $)$ were at par with T3 $(13.87 \mathrm{~kg} /$ plant $)$ whereas the variety Grand Naine exhibited significant difference in bunch weight at different spacing (Table 3) during the year 2014-15. In the year 2015-16, bunch weight recorded in $\mathrm{T} 1(13.40 \mathrm{~kg})$ was at par with $\mathrm{T} 2$ $(13.60 \mathrm{~kg}$ ) but significantly lower than T3 $(14.20 \mathrm{~kg})$ and in the same year T4 (17.40 kg) had significantly lower bunch weight than T5 $(18.20 \mathrm{~kg})$ and T6 (20.80 kg). During the year 2016-17, bunch weight recorded in T1 (12.57 $\mathrm{kg})$ and $\mathrm{T} 2(12.94 \mathrm{~kg})$ were at par with each other and significantly lower from T3 (14.23 $\mathrm{kg})$. In case of Grand Naine, bunch weight recorded in $\mathrm{T} 4(18.31 \mathrm{~kg})$ and $\mathrm{T} 5(18.35 \mathrm{~kg})$ were at par with each other and significantly lower from T6 $(20.51 \mathrm{~kg})$ during the year 2016-17. Pooled analysis revealed that both the varieties Bantal $(14.10 \mathrm{~kg})$ and Grand Naine $(20.70 \mathrm{~kg})$ showed maximum bunch weight at normal spacing $1.8 \mathrm{~m} \times 1.8 \mathrm{~m}$ with one plant per pit (3086 plants/ha) as compared 
to high density planting i.e. in spacing $2 \mathrm{~m} \times 3$ $\mathrm{m}$ (5001plants/ha) and $1.8 \mathrm{~m} \times 3.6 \mathrm{~m}(4629$ plants/ha). This result indicated that bunch weight decreased with the increase in spacing accommodating more number of plants per pit (Fig. 2).

\section{Bunch yield and B:C ratio}

Bunch yield at different system of planting is presented in Table 4. During the year 201415 , bunch yield in variety Bantal was found to be significantly the highest at a spacing of 2 $\mathrm{m} \times 3 \mathrm{~m}$ with 3 suckers per pit (T1: 68.51 $\mathrm{t} / \mathrm{ha}$ ) as compared to the spacing of $1.8 \mathrm{~m} \mathrm{x}$ $3.6 \mathrm{~m}$ with 3 suckers per pit (T2: $62.03 \mathrm{t} / \mathrm{ha}$ ) and the spacing of $1.8 \mathrm{~m} \times 1.8 \mathrm{~m}$ with 1 sucker per pit (T3: $42.79 \mathrm{t} / \mathrm{ha}$ ). In the same year variety Grand Naine recorded significantly the highest yield of $96.52 \mathrm{t} / \mathrm{ha}$ and lowest yield of $64.09 \mathrm{t} / \mathrm{ha}$ at a spacing of $2 \mathrm{~m} \mathrm{x} 3 \mathrm{~m}$ (with 3 suckers per pit) and $1.8 \mathrm{~m} \mathrm{x} 1.8 \mathrm{~m}$ (with 1 sucker per pit) respectively. The variety Bantal recorded the highest yield of $65.39 \mathrm{t} / \mathrm{ha}$ and $62.86 \mathrm{t} / \mathrm{ha}$ at a spacing of $2 \mathrm{~m} \mathrm{x}$ $3 \mathrm{~m}$ (with 3 suckers per pit) during the year 2015-16 and 2016-17 respectively. The variety Grand Naine recorded the highest yield of $87.02 \mathrm{t} / \mathrm{ha}$ and $91.57 \mathrm{t} / \mathrm{ha}$ at a spacing of $2 \mathrm{~m} \mathrm{x} 3 \mathrm{~m}$ (with 3 suckers per pit) during the year 2015-16 and 2016-17 respectively.

The mean yield averaged over three years revealed that (Fig. 3) both the varieties achieved their maximum yield (Bantal: 65.59 t/ha; Grand Naine: $91.7 \mathrm{t} / \mathrm{ha}$ ) at a spacing of 2 $\mathrm{m} \times 3 \mathrm{~m}$ (with 3 suckers per pit). The percent increase in yield of variety Bantal under high density planting was $50.75 \%$ (2 m x 3 m with 3 suckers per pit) and $41.65 \%$ (1.8 m x $3.6 \mathrm{~m}$ with 3 suckers per pit) as compared to normal planting (1.8 m x $1.8 \mathrm{~m}$ with 1 sucker per pit). In variety Grand Naine the percent increase in yield of variety Bantal under high density planting was $43.60 \%(2 \mathrm{~m} \mathrm{x} 3 \mathrm{~m}$ with 3 suckers per pit) and $31.80 \%(1.8 \mathrm{~m} \times 3.6 \mathrm{~m}$ with 3 suckers per pit) as compared to normal planting (1.8 m x $1.8 \mathrm{~m}$ with 1 sucker per pit).

Benefit-cost ratio of different treatments along with mean yield was depicted in Fig.4. The number nearer to glyphs indicated B:C ratio. The economics of production reflected the maximum benefit cost ratio at a spacing of $2 \mathrm{~m} \times 3 \mathrm{~m}$ with 3 suckers per pit for both the varieties Bantal (T1:3.64) and Grand Naine (T4: 3.68) followed by spacing of $1.8 \mathrm{~m}$ x 3.6 m with 3 suckers per pit (T2- 3.12; T5- 3.24) and lower $\mathrm{B}: \mathrm{C}$ ratio was observed in normal planting.

In high density planting more number of plants are accommodated per unit area than conventional method of planting. Adoption of high density planting in banana could reduce the gap between the actual yield and potential yield per unit area. In the present study we observed increase in bunch yield under high density planting. Similar results in banana were reported by Khalequzzaman et al., (2009), Gogoi et al., (2015) and Behera et al., (2015).

From the present investigation it may be concluded that high density planting at a distance of $2 \mathrm{~m} \times 3 \mathrm{~m}$ with 3 suckers per pit (5001 plants/ha) gave significantly the highest yield i.e 65.59 t/ha and 91.70 t/ha with a benefit cost ratio of 3.64 and 3.68 in the varieties Bantal (ABB) and Grand Naine (AAA) respectively as compared to the normal planting of $1.8 \mathrm{~m} \times 1.8 \mathrm{~m}$ with 1 sucker per pit in coastal plain zone of Odisha.

\section{References}

Apshara, E.S. and Sathiamoorthy. S. (2003). Effect of planting more than one sucker per pit on growth and yield of Banana cv. Nendran (AAB). Indian J. Hort. 60(4): 339-342.

Aurore, G., Parfait, B., Fahrasmane, L. 2009. 
Bananas raw materials for making processed food products, Trends in Food Science \& Technology 20:78-91.

Badgujar, C.D. and Gawade, M.H. (2007). Effect of planting density on growth duration and yield of Barsai banana (Musa cavendish). The Orissa J. Hort. . 35(1): 24-28.

Behera, S., Das, A.K. and Panda, P.K.2015 Effect of spacing and variety on growth and yield of banana cv.Grand Naine and Bantal. International Journal of Tropical Agriculture, 33 (3):2025-29.

Gogoi, B., Khangia, B., Baruah, K. and Khound, A.2015. Effect of high density planting and nutrient management on growth and yield of banana cv. Jahaji (Musa, AAA).
International Journal of Agriculture Innovations and Research, 3 (5): 1364-1367

Khalequzzaman, K.M., Rahim, M.A., Mollah, M.R.A. and Kaisar, M.O. 2009. High density planting effect on banana (Musa sapientum) yield. Journal of Agric. Res., 47(4): 359-364

Kumar, S. and Kumar, A. (2011). Effect of High density planting on performance of banana. Bihar J. Hort. 1: 54-56

Nalina, L., Kumar, N., and Sathiamoorthy, S. (2000). Studies on high density planting in banana cv. Robusta (AAA). Influence on vegetative characters. Indian J. Hort. 57 (3): 190195.

\section{How to cite this article:}

Saudamini Swain, Bipin Pradhan and Prakash Patil. 2020. Evaluating Efficacy of High Density Planting in Banana under Coastal Plain Zone of Odisha. Int.J.Curr.Microbiol.App.Sci. 9(11): 152-160. doi: https://doi.org/10.20546/ijcmas.2020.911.018 